\title{
Telemedycyna a niepełnosprawność wzrokowa - szanse, zagrożenia, wyzwania
}

Katarzyna Binder-Olibrowska

(1) https://orcid.org/0000-0003-3022-2440 Uniwersytet Medyczny w Łodzi 


\title{
Streszczenie
}

Telemedycyna rozwijała się od lat, a rozpowszechnienie jej stosowania, do którego przyczyniła się pandemia SARS-CoV-2 sprawiło, że trudno wyobrazić sobie bez niej opiekę zdrowotną w przyszłości. Podobnie jak w przypadku innych działań z zakresu ochrony zdrowia, istnieje potrzeba kontrolowania jakości oddziaływań telemedycznych. Jednym $\mathrm{z}$ wyznaczników tej jakości jest dopasowanie usług do potrzeb ich odbiorców. Od lat zwraca się uwagę na fakt, iż osoby z niepełnosprawnościami mają trudności w dostępie do opieki zdrowotnej. Stąd pytanie, czy telemedycyna jest szansą na osiągnięcie równości, czy też stanowi kolejne zagrożenie dla tej grupy osób? Jakie wyzwania wiążą się ze stosowaniem usług medycznych opartych na nowoczesnych technologiach? Niniejsze opracowanie jest próbą odpowiedzi na te pytania w odniesieniu do osób z dysfunkcjami narządu wzroku.

\section{Słowa kluczowe}

dostęp do opieki zdrowotnej, e-zdrowie, niepełnosprawność wzrokowa, telemedycyna, telezdrowie, wykluczenie cyfrowe.

\section{Telemedicine and visual impairment - opportunities, threats, challenges}

\begin{abstract}
Telemedicine has been evolving for years, and the prevalence of its use spurred by the SARS-CoV-2 pandemic has made it difficult to imagine healthcare without it in the future. As with other healthcare activities, there is a need to control the quality of telemedicine interventions. One of the determinants of this quality is the fit between the services and the needs of the recipients. For years, attention has been drawn to the inequalities in access to health care experienced by people with disabilities. Hence, the question is whether telemedicine is an opportunity to achieve equality or is it another threat for this group of people? What challenges are associated with the use of technology-based health care services? This study is an attempt to answer these questions in relation to people with visual dysfunctions.
\end{abstract}

\section{Keywords}

access to healthcare, e-Health, visual disability, telemedicine, digital divide. 


\section{WPROWADZENIE}

$\mathrm{U}$ stawa o działalności leczniczej z dn. 15 kwietnia 2011 r. definiuje telemedycynę (ang. telemedicine) jako udzielanie świadczeń zdrowotnych za pośrednictwem systemów teleinformatycznych lub systemów łączności. W Polsce tego typu usługi zostały prawnie dopuszczone w październiku 2015 r. wraz z nowelizacją ustawy o systemie informacji w ochronie zdrowia $z$ dn. 28 kwietnia 2011 r. Telemedycyna jest jednym z elementów telezdrowia (ang. telehealth), które odnosi się do klinicznych i nieklinicznych oddziaływań służących zdrowiu i realizowanych na odległość. Pojęciem nadrzędnym dla obu wcześniej wymienionych jest e-zdrowie (ang.e-Health), które swoim zakresem obejmuje ponadto zastosowanie narzędzi i usług technologii informacyjnych i komunikacyjnych (ang. Information and Communication Technologies, ICT) w celu przechowywania i przesyłania dokumentacji medycznej, promocji zdrowia oraz realizacji zadań dydaktycznych i badawczych (Kaczan, 2017, s. 94, za: Łęcka, 2011). W ten zakres wchodzą e-recepty, e-skierowania i e-zwolnienia.

Usługi z zakresu telezdrowia stosowane są na świecie od wielu lat. Ich forma różni się w zależności od sytuacji społeczno-gospodarczej i charakterystyki zdrowotnej społeczeństw danego kraju, a jedną z najczęściej dostrzeganych zalet jest możliwość współpracy między pacjentami i specjalistami z miejsc znacznie od siebie oddalonych (Kufel, Kret, Kozik, Szydziak, 2019). W Polsce, zgodnie z rozporządzeniem Ministra Zdrowia z dnia 31 października 2019 r., poradnie podstawowej opieki zdrowotnej (POZ) od 1 stycznia 2020 r. mają obowiązek zapewnienia pacjentom możliwości korzystania $z$ wizyt online. W świetle regulacji prawnych teleporady podlegają takim samym zasadom jak wizyty stacjonarne. Lekarz ma więc obowiązek udzielania świadczeń zgodnie $z$ aktualną wiedzą medyczną, należytą starannością i z zasadami etyki zawodowej, stosując dostępne metody i środki (Wrześniewska-Wal, Hajdukiewicz, 2020). Zwracając uwagę na zmiany demograficzne zachodzące w Polsce, Bartłomiej Oręziak w 2018 r. (s. 138) stwierdził, że telemedycyna „nie jest już tylko możliwością, ona stała się wręcz koniecznością”. Jednak upowszechnienie jej stosowania nastąpiło głównie pod wpływem pandemii wywołanej wirusem SARS-CoV-2, ogłoszonej w marcu 2020 r. (Mann, Chen, Chunara, Testa, Nov, 2020; Robakowski, Synoweć, 2020). Pandemia znacząco ograniczyła dostęp do usług medycznych w Polsce (Omyła-Rudzka, 2020) i na świecie, jednocześnie uwidaczniając pilną potrzebę cyfryzacji opieki zdrowotnej wraz z wykorzystaniem sztucznej inteligencji (Ting, Deshmukh, Said, Dua, 2020; Ting, Foo, Yang, Sia, Ang, Lin, Chodosh, Mehta, Ting, 2021). Według raportu opublikowanego w sierpniu 2020 r. przez Narodowy Fundusz Zdrowia (NFZ) pacjenci, którzy od marca do czerwca 2020 r. korzystali z teleporad w kontakcie z lekarzem POZ, w większości ocenili je pozytywnie. W badaniu tym zabrakło wyodrębnienia opinii osób z niepełnosprawnościami.

Autorzy analizy kosztów i korzyści płynących z zastosowania telemedycyny twierdzą, że może ona być efektywna medycznie i opłacalna kosztowo, jednak opinia ta nie jest wystarczająco potwierdzona naukowo (Ruzik-Sierdzińska, Sierdziński, 2018). Potrzeba eksploracji obszaru telezdrowia dotyczy również stosowania jej wśród osób z niepełnosprawnościami, na co wskazuje m.in. przegląd systematyczny, dotyczący telerehabilitacji 
osób słabowidzących (Bittner, Wykstra, Yoshinaga, Li, 2020). Andrzej Twardowski (2018) uznał telemedycynę za jedno z osiągnięć modelu medycznego, poszerzające możliwości leczenia i usprawniania osób z niepełnosprawnościami. Inwestycje w telemedycynę znalazły się w punkcie „służba zdrowia” wymienionym jako jeden z ośmiu obszarów wymagających działań w ramach programu „Dostępność Plus”, przyjętego przez Sejm Polski na lata 2018-2025 i mającego na celu podniesienie jakości życia obywateli ze specjalnymi potrzebami.

Celem niniejszej pracy jest przedstawienie szans, zagrożeń i wyzwań związanych ze stosowaniem rozwiązań telemedycznych wśród osób z niepełnosprawnością wzrokową. Artykuł ma charakter przeglądowy i stanowi podsumowanie aktualnego stanu wiedzy na podstawie wybranych aktów prawnych, raportów oraz publikacji naukowych indeksowanych w internetowych bazach danych: PubMed, Google Scholar i CEJSH.

\section{NIEPEŁNOSPRAWNOŚĆ A OPIEKA ZDROWOTNA}

Osoby z niepełnosprawnościami charakteryzują się gorszym ogólnym stanem zdrowia i większymi potrzebami zdrowotnymi w porównaniu z osobami bez niepełnosprawności (Kuper, Mactaggart, Dionicio, Cañas, Naber, Polack, 2018). Z opóźnieniem uzyskują pomoc medyczną oraz doświadczają barier finansowych i niewystarczającej opieki (Davidsson, Södergård, Södergård, 2016).

Od lat opisywane są bariery związane z fizyczną dostępnością opieki stacjonarnej, funduszami, brakiem wiedzy i postawami wobec osób z niepełnosprawnościami, a także trudności komunikacyjne i niedostatki systemu ochrony zdrowia (Morrison, George, Mosqueda, 2008). Współczesne przemiany w opiece zdrowotnej wyznaczają nowy kierunek badań i analiz, dotyczących szans i ograniczeń $\mathrm{w}$ stosowaniu rozwiązań $\mathrm{z}$ zakresu telezdrowia, w tym telemedycyny. Valdez z zespołem (2021) podkreślają, że bez zwrócenia uwagi na projektowanie, wdrażanie i kontekst polityczny telezdrowia może ono przynieść osobom z niepełnosprawnościami więcej szkód niż korzyści.

Według ostatnich dostępnych oszacowań na całym świecie żyje ponad 2,2 miliarda osób $\mathrm{z}$ różnym stopniem niepełnosprawności wzrokowej (World Health Organization, 2019). Według danych udostępnionych przez Biuro Pełnomocnika Rządu do Spraw Osób Niepełnosprawnych w czwartym kwartale 2020 r. 148 tys. 914 osób po 16 roku życia i 15 tys. 944 młodszych Polaków ma orzeczoną niepełnosprawność z powodu uszkodzeń i chorób narządu wzroku (tzw. niepełnosprawność prawna). O wiele więcej jest osób z niepełnosprawnością biologiczną, czyli deklarujących posiadanie problemów ze wzrokiem, ale nieposiadających orzeczenia o niepełnosprawności. Według metaanaliz do 2050 r. krótkowzroczność (wiodąca przyczyna niepełnosprawności wzrokowej) będzie dotyczyła blisko połowy ogólnej populacji świata (Holden, Fricke, Wilson, Jong, Naidoo, Sankaridurg, Wong, Naduvilath, Resnikoff, 2016). Dysfunkcja wzroku oddziałuje zarówno na funkcjonowanie fizyczne, jak i na dobrostan psychospołeczny osób nią dotkniętych (Court, McLean, Guthrie, Mercer, Smith, 2014). Wyniki badań wskazują, że w porównaniu z osobami bez niepełnosprawności wzrokowej osoby słabowidzące i niewidome mają niższy 
poziom zdrowia funkcjonalnego i deklarowanego w samoocenie, częściej zapadają na choroby przewlekłe oraz doświadczają niższego poziomu dobrostanu rozumianego jako satysfakcja z życia, pozytywny afekt, brak objawów depresyjnych i poczucia samotności (Wettstein, Spuling, Hans-Werner-Wahl, 2021). Z niepełnosprawnością wzrokową związane są szczególne potrzeby i trudności ujawniające się w trakcie hospitalizacji (Waterman, Webb, 1992; Carlson, Howe, Pedersen, Yoder, 2020) oraz korzystania ze świadczeń ambulatoryjnych, m.in. z zakresu stomatologii (Lim, Im, Cho, 2019; Campos, Cartes-Velásquez, 2020) czy profilaktyki (Assi, Varadaraj, Shakarchi, Sheehan, Reed, Ehrlich, Swenor, 2020). Przegląd literatury opublikowany w 2019 r. wskazuje, że osoby z niepełnosprawnościami sensorycznymi mają trudności z uzyskaniem właściwej opieki zdrowotnej, a specjalistom brakuje przygotowania do pracy z nimi (Campos, Cartes-Velásquez, 2019).

\section{SZANSE WYNIKAJĄCE Z ZASTOSOWANIA TELEMEDYCYNY W PROFILAKTYCE I LECZENIU OSÓB Z DYSFUNKCJAMI WZROKU}

Rozwiązania z zakresu telemedycyny znajdują zastosowanie zarówno w podstawowej, jak i w specjalistycznej opiece zdrowotnej. Dla przykładu, w przeglądzie systematycznym z 2019 r. Caffery z zespołem podsumowują, że w okulistyce telemedycyna jest wykorzystywana w ramach konsultacji, badań przesiewowych, triage i zdalnego nadzoru nad pacjentami z różnymi rozpoznaniami. Bardziej szczegółowo:

- U pacjentów z zaćmą telemedycyna oparta na sztucznej inteligencji wykorzystywana jest w celach diagnostycznych i terapeutycznych (Ting, Ang, Mehta, Ting, 2019).

- U osób chorujących na cukrzycę rozwiązania telemedyczne umożliwiają wykrycie i monitorowanie postępu retinopatii cukrzycowej oraz edukację zdrowotną, a tym samym są ważnym elementem prewencji utraty wzroku (Hautala, Aikkila, Korpelainen, Keskitalo, Kurikka, Falck, Bloigu Alanko, 2014; Vujosevic, Modena, 2016; Wong, Sabanayagam, 2019; Gunasekeran, Ting, Tan, Wong, 2020).

- Według niektórych źródeł telemedycyna umożliwia zarówno badania przesiewowe w kierunku jaskry, jak i długotrwałe monitorowanie pacjentów ze zdiagnozowaną chorobą (Chandrasekaran, Kass, Thangamathesvaran, Mendez, Khouri, Szirth, Khouri, 2019; Gan, Liu, Stagg, Rathi, Pasquale, Damji, 2020).

- Telemedycyna może być skuteczną formą pomocy okulistycznej w stosunku do osób przebywających w instytucjach opiekuńczych, które ze względu na swoją sytuację, tj. zależność od innych i izolację, mają utrudniony dostęp do opieki zdrowotnej (Bon, Ghemame, Fantou, Philliponnet, Mouriaux, 2020).

- U pacjentów z jednostronnymi ubytkami pola widzenia powstałymi wskutek udaru $\mathrm{w}$ tylnej okolicy ciemieniowej rehabilitacja prowadzona w warunkach domowych i ze wsparciem $\mathrm{w}$ postaci konsultacji telemedycznych przyczynia się do poprawy w zakresie pola widzenia oraz, wtórnie, do usprawnienia zdolności czytania (Gall, Sabel, 2012).

- Telemedycyna przekłada się pozytywnie na gromadzenie danych epidemiologicznych, współpracę interdyscyplinarną, koszty leczenia, a także satysfakcję pacjenta, 
na co wskazuje włoski przykład monitorowania retinopatii cukrzycowej (Vujosevic, Modena, 2016).

- Śwaidczenia telemedyczne wspierają rehabilitację osób z niepełnosprawnością wzrokową (Christy, Keeffe, 2020).

- Telemedycyna umożliwia udzielanie porad na odległość oraz kwalifikowanie do pomocy w trybie nagłym w szczególnych okresach, co zostało udowodnione w czasie pandemii SARS-CoV-2 (Das, Rani, Vaddavalli, 2020).

W ten sposób teleokulistyka daje szanse na profilaktykę pierwotną (stosowaną zanim problem zdrowotny wystąpi) i wtórną (nakierowaną na osoby ze stwierdzoną chorobą narządu wzroku), minimalizując ryzyko powstawania lub pogłębiania się niepełnosprawności. Stosowanie narzędzi z zakresu telemedycyny znalazło się wśród rekomendacji mających zapobiegać wpływowi COVID-19 na opiekę okulistyczną (Brandão-de-Resende, Diniz-Filho, de Almeida Brito, Vasconcelos-Santos, 2020) i opisywane jest jako standard w opiece okulistycznej w przyszłości (Mack, Fraser-Bell, 2021). W 2005 r. Tang z zespołem (Tang, Morales, Ricur, Schiffman, 2005) jako jedną z zalet teleokulistyki wskazał dostępność do usług zdrowotnych dla osób z obszarów niewystarczająco objętych opieką, jej opłacalność i możliwość zaangażowania bogatszych krajów w pomoc medyczną. Piętnaście lat później te argumenty przemawiające na rzecz telemedycyny pozostają aktualne i odnoszą się również do innych dziedzin medycyny. Telemedycyna niesie nowe możliwości w zakresie profilaktyki, diagnozy i leczenia oraz ułatwia podtrzymanie kontaktu pacjenta $\mathrm{z}$ personelem medycznym $\mathrm{w}$ celu kontroli jego stanu zdrowia m.in. $\mathrm{w}$ takich dziedzinach, jak: kardiologia (Lin, Yuan, Huang, Zhang, Mai, Wang, Lin i in. 2017; Król, Brodny, 2018), gastroenterologia (Siegel, 2017) czy psychiatria (Krzystanek, Matuszczyk, Krupka-Matuszczyk, Koźmin-Burzyńska, Segiet, Przybyło, 2020). Okazuje się skuteczna również w przypadku szczególnych grup pacjentów, jak np. osób z niepełnosprawnością intelektualną (Krysta, Romańczyk, Diefenbacher, Krzystanek, 2021). Zyskują na tym zarówno pacjenci, świadczeniodawcy, jak i szeroko pojęty system ochrony zdrowia.

Najogólniej ujętą korzyścią telemedycyny dla osób z niepełnosprawnościami jest poprawa opieki nad nimi (Fundacja Telemedyczna Grupa Robocza, 2018).

Jedną z najczęściej wymienianych zalet telemedycyny jest ograniczanie konieczności przybycia pacjenta do placówki ochrony zdrowia. W literaturze wielokrotnie opisywano bariery w dostępie do usług medycznych doświadczane przez osoby z niepełnosprawnościami. Wynikają one z ich ograniczonej mobilności, potrzeby zorganizowania sobie transportu, zadbania o pomoc drugiej osoby oraz z trudności w odnalezieniu się w przestrzeni publicznej (Valdez, Rogers, Claypool, Trieshmann, Frye, Wellbeloved-Stone, Kushalnagar, 2021). W przypadku osób słabowidzących i niewidomych teleporady eliminują również trudności z poruszaniem się w niedostosowanej przestrzeni, znalezieniem właściwego gabinetu, czy z podążaniem za kolejką.

Kolejną wartością telemedycyny w odniesieniu do opisywanej grupy osób jest poprawa bezpieczeństwa. Dysfunkcje wzroku zwiększają prawdopodobieństwo poślizgnięć, upadków i spowodowanych nimi urazów (Dhital, Pey, Stanford, 2010; Reed-Jones, Solis, Lawson, Loya, Cude-Islas, Berger, 2013; Krzepota, Sadowska, 2015). Ryzyko takich niepomyślnych zdarzeń rośnie $\mathrm{w}$ niesprzyjających warunkach pogodowych - w czasie 
deszczu, opadów śniegu, przy ograniczonym świetle dziennym lub o zmroku, kiedy pogarsza się widoczność. Takie okoliczności utrudniają samodzielne poruszanie się na zewnątrz i mogą zniechęcać do opuszczania domu (Salminen, Karhula, 2014). Możliwość zasięgnięcia teleporady wydaje się być opcją zapobiegającą rezygnacji z wizyty lekarskiej.

Również z perspektywy podnoszenia bezpieczeństwa można spojrzeć na telemedycynę stosowaną w wyjątkowych okresach. Teleporady w czasie pandemii SARS-CoV-2 umożliwiły zachowanie ciągłości opieki nad pacjentami bez konieczności ich wizyty w placówce medycznej, a tym samym stały się jednym ze sposobów zapobiegania rozprzestrzenianiu się wirusa. W codziennym funkcjonowaniu w przestrzeni publicznej (w sklepie, w kolejce, w środkach transportu publicznego) utrzymanie zalecanego dystansu społecznego osobom słabowidzącym i niewidomym może sprawiać trudność. Osoby z dysfunkcjami wzroku polegają w większym stopniu niż pozostałe na zmyśle dotyku (np. w czasie, gdy są prowadzone przez przewodnika lub dotykowo odbierają informacje z otoczenia). Sprawia to, że znajdują się w grupie zwiększonego ryzyka zachorowania na choroby wirusowe, co było podnoszone w czasie pandemii SARS-CoV-2 (Christy, Keeffe, 2020). Korzystanie z porad zdalnych minimalizuje potencjalne niebezpieczeństwa.

Usługi zdalne ułatwiają osobom doświadczającym niepełnosprawności nawiązywanie kontaktu ze światem zewnętrznym oraz zdobywanie informacji. W ten sposób nabierają one znaczenia włączającego (Żuchowska-Skiba, 2020). W przypadku lekarskich wizyt stacjonarnych osoby słabowidzące i niewidome mają utrudniony dostęp do informacji - często nie są w stanie samodzielnie odczytać treści zamieszczonych na tablicach informacyjnych, wypełnić otrzymanych druków lub zapoznać się z dostępnymi materiałami edukacyjnymi. Udostępnienie tego typu treści $\mathrm{w}$ formie elektronicznej może $\mathrm{w}$ istotny sposób podnieść samodzielność i świadomość zdrowotną osób z dysfunkcją narządu wzroku. Ponadto w trakcie wizyt stacjonarnych osoby te mogą poczuć się niekompetentne i lekceważone, gdy personel medyczny zwraca się do osób im towarzyszących, zamiast bezpośrednio do nich. Teleporady, odbywające się w zaciszu domowym, dają szansę na większą niezależność osób z niepełnosprawnościami i na wzmocnienie ich poczucia samostanowienia. Stanowią również odciążenie dla ich opiekunów/osób towarzyszących.

\section{ZAGROŻENIA ZWIĄZANE Z WDRAŻANIEM USŁUG TELEMEDYCZNYCH W ŚRODOWISKU OSÓB Z NIEPEŁNOSPRAWNOŚCIĄ WZROKOWĄ}

Jak pisze Kanownik (2017, s. 625, za Meyer i in. 2013): „dostęp do usług medycznych powinien być zależny jedynie od stanu zdrowia pacjentów, a nie od ich statusu społeczno-ekonomicznego". W przypadku osób z niepełnosprawnościami sensorycznymi zarówno ich stan zdrowia, jak i sytuacja życiowa, mogą generować trudności w dostępie do ochrony zdrowia.

Jednym $\mathrm{z}$ podstawowych zagrożeń $\mathrm{w}$ stosowaniu telemedycyny są bariery cyfrowe. Wynikają one z niedostatecznej infrastruktury teleinformatycznej, niewystarczającego dostępu do potrzebnego sprzętu i oprogramowania oraz z braku umiejętności korzystania z nich. Problem ten na całym świecie dotyczy szczególnie osób mieszkających na 
terenach wiejskich, osiągających niskie przychody i doświadczających niepełnosprawności. W Polsce w ostatnich latach znacząco przybyło osób korzystających $\mathrm{z}$ internetu i obecnie nie ustępujemy w tym względzie innym krajom europejskim (Garwol, 2019). Jednak osoby z niepełnosprawnościami znacząco rzadziej korzystają z internetu w porównaniu $\mathrm{z}$ przedstawicielami populacji ogólnej i nadal są zagrożone wykluczeniem cyfrowym (Duplaga, 2017; Fundacja Telemedyczna Grupa Robocza, 2018). Z ryzykiem tym związane są zmienne socjodemograficzne, takie jak: stopień niepełnosprawności (Masłyk, Migaczewska, 2014), starszy wiek, życie w pojedynkę i ograniczenia finansowe (Scholz, Yalcin, Priestley, 2017).

Dysfunkcje wzroku wymuszają wyposażenie użytkowników w specjalistyczne oprogramowania, np. udźwiękawiające lub powiększające tekst oraz w urządzenia asystujące, jak np.: lupy, powiększalniki ekranu czy drukarki brajlowskie. Wskazane jest również rozwijanie umiejętności personalizowania ułatwień dostępu do indywidualnych potrzeb. Stąd wynika potrzeba specjalistycznych szkoleń, co generuje koszty czasowe i finansowe znacząco wyższe od tych, które ponoszą osoby bez niepełnosprawności. Jednocześnie wśród osób z niepełnosprawnościami odnotowuje się wyższy wskaźnik ubóstwa niż w populacji ogólnej (Czapliński, Panek, 2015; Allen, Smith, 2020).

Wbrew powszechnym w Polsce skojarzeniom, telemedycyna nie opiera się wyłącznie na rozmowie pacjenta $\mathrm{z}$ lekarzem przez telefon. Może ona przybierać formę wideokonsultacji i może jej towarzyszyć wykorzystanie tzw. peryferyjnych urządzeń służących do pomiaru różnych funkcji fizjologicznych (ciśnieniomierze, spirometry, glukometry). W kontekście niepełnosprawności sensorycznych pojawia się tutaj kwestia wyposażenia pacjentów w narzędzia, które będą dostosowane do ich potrzeb i możliwości odbiorczych (Annaswamy, Verduzco-Gutierrez, Frieden, 2020).

Kolejnym obszarem, w którym mogą pojawić się bariery, zarówno w stacjonarnym, jak i w zdalnym kontakcie osoby $\mathrm{z}$ dysfunkcją narządu wzroku z personelem medycznym, jest komunikacja. Robakowski i Synoweć (2020) stwierdzają, że proces diagnostyczny w trakcie teleporad może być zakłócany nieznajomością żargonu medycznego przez pacjentów oraz ich nieumiejętnością opisywania dolegliwości. Dysfunkcje wzroku utrudniają samodzielną ocenę stanu zdrowia, uniemożliwiając np. zaobserwowanie zmian pojawiających się na skórze i dokładne opisanie ich. Trudności w komunikacji mogą wynikać ponadto z niedostosowania materiałów informacyjnych, dokumentów medycznych i wykorzystywanych narzędzi (sprzętów, oprogramowań, aplikacji, stron internetowych) do specjalnych potrzeb użytkowników (Annaswamy, Verduzco-Gutierrez, Frieden, 2020). Na niedostosowanie materiałów multimedialnych i stron internetowych do potrzeb osób z niepełnosprawnościami zwróciła uwagę Najwyższa Izba Kontroli w $2015 \mathrm{r}$. W trakcie wizyt stacjonarnych personel medyczny niejednokrotnie nie potrafi w odpowiedni sposób zakomunikować osobie z dysfunkcją wzroku np. położenia leżanki w gabinecie. W przypadku porad zdalnych podobne błędy komunikacyjne mogą na przykład się pojawić, gdy lekarz poprosi osobę niewidomą o nakierowanie kamery na twarz, nie dając jej dokładniejszych instrukcji, w jaki sposób może ten cel osiągnąć.

Kolejnym zagrożeniem i obawą pacjentów jest utrata prywatności i bezpieczeństwa danych (Mold, Hendy, Lai, de Lusignan, 2019). W odniesieniu do całego systemu e-zdro- 
wia jest to powiązane $\mathrm{z}$ kwestią bezpieczeństwa cyfrowego i ochrony przed cyberatakami. Stąd wynika konieczność wprowadzania odpowiednich zabezpieczeń od strony informatycznej oraz rozwijania świadomości niebezpieczeństw i odpowiedzialnej postawy u świadczeniodawców i świadczeniobiorców. Wykazano, że z dysfunkcją narządu wzroku wiąże się wyższe ryzyko doświadczania cyberprzemocy (Heiman, Olenik-Shemesh, 2017). Prywatność pacjentów może być ponadto zagrożona, gdy nie nabędą kompetencji cyfrowych umożliwiających im samodzielne nawiązanie i podtrzymanie kontaktu z personelem medycznym, a w efekcie osoby trzecie staną się świadkami ich wizyty lekarskiej lub uzyskają dostęp do dotyczącej ich dokumentacji.

W czasie pandemii SARS-CoV-2 osoby z chorobami przewlekłymi częściej zgłaszały niezadowolenie $\mathrm{z}$ dominacji zdalnej formy kontaktu z lekarzem nad tradycyjnym, bezpośrednim kontaktem (Robakowski, Synoweć, 2020). Dlatego niezbędne jest, by zachować możliwość bezpośredniego kontaktu ze specjalistą. Dotyczy to również pacjentów z niepełnosprawnościami, często doświadczających wielochorobowości. Usługi świadczone w formie zdalnej, jeśli staną się dominującą opcją kontaktu ze świadczeniodawcą, mogą być kolejnym elementem wykluczenia społecznego, co zaprzecza idei rehabilitacji psychospołecznej, opierającej się na włączaniu osób z niepełnosprawnościami w środowisko.

\section{WYZWANIA ZWIĄZANE Z WDRAŻANIEM TELEMEDYCYNY WŚRÓD OSÓB Z NIEPEŁNOSPRAWNOŚCIĄ WZROKOWĄ}

W Polsce telemedycyna najczęściej kojarzy się z rozmową z lekarzem przez telefon. Jednak współczesne rozwiązania z zakresu telezdrowia oferują o wiele więcej możliwości, wykorzystując innowacje cyfrowe, np.: sztuczną inteligencję (ang. artificial intelligence, $A I$ ), telekomunikację piątej generacji (5G), sieci i internet rzeczy (ang. networks and the Internet of Things, IoT) (Li, Liu, H., Ting, Jeon, Chan, Kim, Sim, Thomas, Lin, Chen, Sakomoto, Loewenstein, Lam, Pasquale, Wong, Lam, Ting, 2021). Wykorzystywanie tego potencjału jest najbardziej ogólnym wyzwaniem systemów ochrony zdrowia na całym świecie.

Telemedycyna może ułatwić funkcjonowanie i pozytywnie wpłynąć na zdrowie szczególnych populacji, w tym osób słabowidzących i niewidomych. Aby tak się stało, istotne jest uwzględnianie ich specyficznych potrzeb i możliwości. Dotychczas głównie usługi medyczne świadczone stacjonarnie, $\mathrm{w}$ bezpośrednim kontakcie z pacjentem, były poddawane analizie pod kątem ich dostępności dla osób doświadczających niepełnosprawności. Obecnie, gdy stosowanie telemedycyny upowszechnia się, i gdy staje się ona nie tylko uzupełnieniem, ale również alternatywą dla tradycyjnych form opieki zdrowotnej, istnieje potrzeba rewizji tematu dostępności dla osób z różnymi niepełnosprawnościami (Annaswamy, Verduzco-Gutierrez, Frieden, 2020). Przeciwdziałanie nierównościom w dostępie do opieki zdrowotnej, niezależnie od jej formy, jest wyzwaniem współczesnych systemów ochrony zdrowia.

Autorzy pracy poświęconej telerehabilitacji osób z wadą słuchu (Pankowska, Rostkowska, Skarżyński, 2015) stwierdzają, że coraz chętniej z teleopieki korzystają nie tylko osoby zamieszkujące daleko od placówki medycznej i aktywne, ale także osoby starsze 
i samotne. Ponadto, za Pauline Mashima i Charlesem Doarnem (2008), wskazują, że $\mathrm{w}$ planowaniu tego typu pracy z pacjentem powinny być wzięte pod uwagę m.in. jego możliwości motoryczne, poznawcze, współdziałanie z rodziną i otoczeniem oraz swoboda dostępu i obsługi potrzebnych urządzeń. Są to wskazówki istotne do stosowania również w innych obszarach telezdrowia.

Dostępność cyfrowa wydaje się być kluczowym tematem. Usługi z zakresu e-zdrowia, obejmujące swoim zakresem telemedycynę, jeśli nie będą dostosowane do specjalnych potrzeb użytkowników z niepełnosprawnościami, staną się kolejnym źródłem już doświadczanych przez nich nierówności w zdrowiu i w dostępie do opieki zdrowotnej (Crawford, Serhal, 2020). We współczesnym świecie wykluczenie cyfrowe przyczynia się do wykluczenia społecznego (Garwol, 2019; Żuchowska-Skiba, 2020). Zdaniem Katarzyny Garwol (2019), wykluczenie cyfrowe wynika z przyczyn obiektywnych (związanych z brakiem dostępu do internetu lub z barier finansowych) oraz z przyczyn subiektywnych (strach przed nowymi technologiami lub brak motywacji do rozwijania umiejętności posługiwania się nimi), które autorka określa jako „samowykluczenie cyfrowe". Stąd wynikają wyzwania takie jak:

- Rozwijanie infrastruktury teleinformatycznej i zwiększanie dostępu do urządzeń elektronicznych, internetu i technologii asystujących.

- Znoszenie barier finansowych poprzez programy pomocowe, ulgi podatkowe i zwiększanie udziału osób z niepełnosprawnościami na rynku pracy (sprzyjające podniesieniu ich statusu socjoekonomicznego).

- Propagowanie idei projektowania uniwersalnego, dzięki któremu sprzęty, programy i aplikacje będą dostępne dla większej grupy odbiorców, a przez to tańsze.

- Zachęcanie do rozwijania umiejętności cyfrowych.

- Propagowanie szkoleń doskonalących umiejętności cyfrowe świadczeniodawców i pacjentów.

- Wdrażanie i kontrola przestrzegania standardów dostępności.

Powyższe potrzeby opisali m.in. Tarricone i Rognoni (2020) oraz Valdez i in. (2021). Sytuacja pandemii COVID-19, która z dnia na dzień wymusiła na nas zmianę sposobu funkcjonowania, szczególnie wyraźnie pokazała, że posiadanie umiejętności cyfrowych jest istotnym zasobem o znaczeniu profilaktycznym. Osoby, które ich wcześniej nie nabyły, potrzebowały dłuższego czasu, aby nauczyć się np. obsługi komunikatorów, były bardziej zależne od innych oraz narażone na nierówności w różnych dziedzinach życia społecznego.

Rynek usług cyfrowych dynamicznie się rozwija. Kolejne dziedziny życia przechodzą w świat wirtualny (poza zdrowiem są to m.in.: usługi administracyjne, zakupy, edukacja). Stąd wynika potrzeba regularnego monitorowania, czy osoby z niepełnosprawnościami posiadają dostęp do urządzeń elektronicznych i internetu, czy są wyposażone w kompetencje, by się nimi sprawnie i samodzielnie posługiwać, oraz czy oferowane usługi są zaprojektowane w sposób dla nich dostępny. Regularne analizy pozwolą tworzyć programy pomocy finansowej i szkoleniowej, dedykowane osobom i instytucjom najbardziej ich potrzebującym.

Odnosząc się do wspomnianych wyżej barier komunikacyjnych, można wskazać następujące wyzwania dla rozwoju telemedycyny: 
- Potrzeba rozwijania świadomości zdrowotnej u pacjentów, tak aby potrafili zrozumiale opisywać swoje dolegliwości i potrzeby, samodzielnie badać parametry zdrowotne metodami dostępnymi w warunkach domowych, reagować na sygnały zagrożenia dla ich zdrowia oraz prosić inne osoby o opisanie zmian na ciele, których nie są w stanie samodzielnie zarejestrować.

- Doskonalenie umiejętności komunikacyjnych personelu medycznego w kontakcie $\mathrm{z}$ pacjentami z dysfunkcjami narządu wzroku. Powinno się to przełożyć na:

a) wybieranie dostępnych form komunikacji - programów wspierających wspomniane ułatwienia dostępu,

b) przygotowywanie dokumentów, zaleceń, materiałów edukacyjnych, stron internetowych w sposób dostępny (czyli taki, aby osoba $\mathrm{z}$ dysfunkcją wzroku mogła np. przetworzyć tekst na mowę, powiększyć go lub zmienić kontrast) oraz

c) świadomość trudności i potrzeb wynikających z niepełnosprawności wzrokowej - np. osoba słabowidząca lub niewidoma, która nie jest w stanie robić odręcznych notatek, może skorzystać z nagrania głosowego rozmowy z lekarzem.

Wdrażanie telemedycyny wiąże się również ze zmianami w organizacji opieki zdrowotnej, które mogą wymagać współpracy ze specjalistami z różnych dziedzin, koordynacji i integracji działań oraz większej otwartości na to, by rodziny stawały się członkami zespołów terapeutycznych. Christy i Keeffe (2020) opisując doświadczenia z telerehabilitacji osób z dysfunkcjami narządu wzroku podkreślili, że wdrożone inicjatywy były możliwe dzięki współpracy interdyscyplinarnej i zaangażowaniu rodzin pacjentów. W przypadku osób doświadczających niepełnosprawności i wielochorobowości, wartościowe byłyby telekonsultacje lub telekonsylia, w trakcie których zachodziłaby wymiana informacji pomiędzy różnymi specjalistami, co mogłoby przyspieszyć proces diagnostyczno-terapeutyczny i odciążyłoby pacjenta z konieczności odbywania wielu wizyt lekarskich. Dla zwiększania efektywności różnych działań w ramach e-zdrowia potrzebne jest wsłuchanie się w głos pacjentów - badanie ich potrzeb i doświadczeń oraz angażowanie w audyty dostępności.

\section{PODSUMOWANIE}

Analizy raportów, aktów prawnych i programów zdrowotnych wskazują, że w Polsce osoby z niepełnosprawnościami nie uzyskują opieki zdrowotnej wystarczającej jakości (Szeroczyńska, 2015; Wołoszyn-Cichocka, 2017). Współczesne przemiany wymuszają dwutorowe i równoległe doskonalenie opieki zdrowotnej - zarówno w zakresie świadczeń stacjonarnych, jak i zdalnych.

Z jednej strony, usługi świadczone na odległość są zasobem, który może podnieść jakość życia osób z niepełnosprawnościami. Z drugiej zaś, ich stosowanie wiąże się z ryzkiem wykluczenia społecznego tej grupy. Dlatego ważne jest, żeby telemedycyna pozostawała opcją do wyboru, a osoby z niepełnosprawnościami były przygotowane do podejmowania aktywności w świecie wirtualnym i rzeczywistym. 
Rozwiązania mające na celu poprawę jakości usług z zakresu telezdrowia muszą uwzględniać specyfikę poszczególnych rodzajów niepełnosprawności. Dysfunkcje sensoryczne wydają się szczególnie narażać na doświadczanie barier i nierówności w tym zakresie. Opisane szanse, zagrożenia i wyzwania w pewnym stopniu będą dotyczyć również osób głuchoniewidomych, jednak zaburzenia słuchu współwystępujące z dysfunkcją wzroku wymagają odrębnej analizy.

Ze względu na psychospołeczny charakter niniejszego opracowania nie opisano szerzej aspektów prawnych, ekonomicznych i technologicznych, z których wywodzą się specyficzne wyzwania dla upowszechniania telemedycyny w odniesieniu do populacji ogólnej, jak i szczególnych grup pacjentów.

Podsumowując, należy stwierdzić, że pandemia COVID-19 przyczyniła się do rozwoju informatyzacji w medycynie, uwypukliła problemy polityki zdrowotnej, ale też pozwoliła dostrzec szanse płynące z telemedycyny (Robakowski, Synoweć, 2020). W polskich doniesieniach niewystarczająco zauważono w tym czasie osoby z niepełnosprawnościami. Stąd wyłania się potrzeba badań i rutynowego uwzględniania tej subpopulacji w rozwijaniu telemedycyny i e-zdrowia tak, aby stanowiły one szansę, a nie kolejne zagrożenie eskalujące nierówności w dostępie do opieki zdrowotnej. 


\section{BIBLIOGRAFIA}

Allen, P.M., Smith, L. (2020). SARS-CoV-2 self-isolation: recommendations for people with a vision impairment. Eye, 34.7, 1183-1184. https://doi.org/10.1038/s41433-020-0917-x

Annaswamy, T.M., Verduzco-Gutierrez, M., Frieden, L. (2020). Telemedicine barriers and challenges for persons with disabilities: COVID-19 and beyond. Disability and health journal, 13(4), 100973. https://doi.org/10.1016/j.dhjo.2020.100973

Assi, L, Varadaraj, V., Shakarchi, A.F., Sheehan, O.C., Reed, N.S., Ehrlich, J.R., Swenor, B.K. (2020). Association of Vision Impairment With Preventive Care Use Among Older Adults in the United States. JAMA Ophthalmol, 138(12), 1298-1306. https://doi. org/10.1001/jamaophthalmol.2020.4524

Bittner, A.K., Wykstra, S.L., Yoshinaga, P.D., Li, T. (2015). Telerehabilitation for people with low vision. The Cochrane database of systematic reviews, 8 , CD011019. https://doi. org/10.1002/14651858.CD011019.pub2

Biuro Pełnomocnika Rządu do Spraw Osób Niepełnosprawnych. Orzekanie o niepełnosprawności i stopniu niepełnosprawności - statystyki. http://www.niepelnosprawni.gov. $\mathrm{pl} / \mathrm{p}, 164$,orzekanie-o-niepelnosprawnosci-i-stopniu-niepelnosprawnosci-statystyki

Bon, V., Ghemame, M., Fantou, P., Philliponnet, A., Mouriaux, F. (2020). Feedback on ophthalmologic telemedicine in a nursing home. Journal francais d'ophtalmologie, S01815512(20)30392-2. https://doi.org/10.1016/j.jfo.2020.09.002

Brandão-de-Resende, C., Diniz-Filho, A., de Almeida Brito, F., Vasconcelos-Santos, D.V. (2021). SARS-CoV-2 and COVID-19 for the ophthalmologist. Clinical \& Experimental Ophthalmology, 49(1), 70-80. https://doi.org/ 10.1111/ceo.13877

Caffery, L.J., Taylor, M., Gole, G., Smith, A.C. (2019). Models of care in tele-ophthalmology: A scoping review. Journal of Telemedicine and Telecare, 25(2), 106-122. https://doi. org/10.1177/1357633X17742182

Campos, V., Cartes-Velásquez, R. (2019). Health care of people with visual or hearing disabilities. Revista Medica de Chile, 147(5), 634-642. https://doi.org/10.4067/s003498872019000500634

Campos, V., Cartes-Velásquez, R. (2020). Developing competencies for the dental care of people with sensory disabilities: A pilot inclusive approach. Cumhuriyet Dental Journal, 23(2), 107-115. https://doi.org/10.7126/cumudj.706518

Carlson, C., Howe, T., Pedersen, C., Yoder, L.H. (2020). Caring for Visually Impaired Patients in the Hospital: A Multidisciplinary Quality Improvement Project. The American journal of nursing, 120(5), 48-55. https://doi.org/10.1097/01.NAJ.0000662820.87519.52

Chandrasekaran, S., Kass, W., Thangamathesvaran, L., Mendez, N., Khouri, P., Szirth, B.C., Khouri, A.S. (2020). Tele-glaucoma versus clinical evaluation: The New Jersey Health Foundation Prospective Clinical Study. Journal of Telemedicine and Telecare, 26(9), 536-544. https://doi.org/10.1177/1357633X19845273

Christy, B., Keeffe, J. (2020). Telerehabilitation during COVID-19: Experiences in service delivery from South India. Indian Journal of Ophthalmology, 68(7), 1489-1490. https:// doi.org/10.4103/ijo.IJO_1197_20 
Court, H., McLean, G., Guthrie, B., Mercer, S.W., Smith, D.J. (2014). Visual impairment is associated with physical and mental comorbidities in older adults: a cross-sectional study. BMC medicine, 12(1), 181, 1-8. https://doi.org/10.1186/s12916-014-0181-7

Crawford, A., Serhal, E. (2020). Digital health equity and COVID-19: the innovation curve cannot reinforce the social gradient of health. Journal of medical Internet research, 22(6), e19361, 1-5. https://doi.org/10.2196/19361

Czapliński, J., Panek, T. (2015). Diagnoza społeczna 2015. Warunki i jakość życia Polaków. Contemporary economics, 9(4). www.diagnoza.com/pliki/raporty/Diagnoza_raport_2015. pdf

Das, A.V., Rani, P.K.,Vaddavalli, P.K. (2020). Tele-consultations and electronic medical records driven remote patient care: Responding to the COVID-19 lockdown in India. Indian journal of ophthalmology, 68(6), 1007-1012. https://doi.org/10.4103/ijo. IJO_1089_20

Davidsson, N., Södergård, B., Södergård, B. (2016). Access to Healthcare among People with Physical Disabilities in Rural Louisiana. Social Work In Public Health, 31(3), 188-195. https://doi.org/10.1080/19371918.2015.1099496

Dhital, A., Pey, T., Stanford, M.R. (2010). Visual loss and falls: a review. Eye, 24(9), $1437-$ 1446. https://doi.org/10.1038/eye.2010.60

Duplaga, M. (2017). Digital divide among people with disabilities: Analysis of data from a nationwide study for determinants of Internet use and activities performed online. PloS one, 12(6), e0179825, 1-19. https://doi.org/10.1371/journal.pone.0179825

Fundacja Telemedyczna Grupa Robocza (2018). Raport Jak skutecznie wykorzystać potencjał telemedycyny w polskim systemie ochrony zdrowia? http://telemedycyna-raport.pl/api/file/ events/rtgr/DZP_raportTGR\%20raport-www.pdf

Gall, C., Sabel, B.A. (2012). Reading performance after vision rehabilitation of subjects with homonymous visual field defects. $P M \& R$ : the journal of injury, function, and rehabilitation, 4(12), 928-935. https://doi.org/10.1016/j.pmrj.2012.08.020

Gan, K., Liu, Y., Stagg, B., Rathi, S., Pasquale, L.R., Damji, K. (2020). Telemedicine for Glaucoma: Guidelines and Recommendations. Telemedicine journal and e-health: the official journal of the American Telemedicine Association, 26(4), 551-555. https://doi. org/10.1089/tmj.2020.0009

Garwol, K. (2019). Stopień umiejętności korzystania z technologii cyfrowych a wykluczenie społeczne na przykładzie osób niepełnosprawnych, starszych i ubogich. Nierówności społeczne a wzrost gospodarczy, 58, 47-68. https://www.ceeol.com/search/article-detail id $=790372$

Gunasekeran, D.V., Ting, D., Tan, G., Wong, T.Y. (2020). Artificial intelligence for diabetic retinopathy screening, prediction and management. Current opinion in ophthalmology, 31(5), 357-365. https://doi.org/10.1097/ICU.0000000000000693

Hautala, N., Aikkila, R., Korpelainen, J., Keskitalo, A., Kurikka, A., Falck, A., Bloigu, R., Alanko, H. (2014). Marked reductions in visual impairment due to diabetic retinopathy achieved by efficient screening and timely treatment. Acta Ophthalmologica, 92(6), 582-587. https://doi.org/10.1111/aos.12278 
Heiman, T., Olenik-Shemesh, D. (2017). Cyberbullying involvement of adolescents with low vision compared to typical adolescents, as related to perceived social support. Journal of Aggression, Maltreatment \& Trauma, 26(2), 105-115. https://doi.org/10.1080/10926771.2 016.1228725

Holden, B.A., Fricke, T.R., Wilson, D.A., Jong, M., Naidoo, K.S., Sankaridurg, P., Wong, T.Y., Naduvilath, T.J., Resnikoff, S. (2016). Global Prevalence of Myopia and High Myopia and Temporal Trends from 2000 through 2050. Ophthalmology, 123(5), 1036-1042. https:// doi.org/10.1016/j.ophtha.2016.01.006

Kaczan, D. (2017). Telemedycyna w prawie polskim i kilka uwag na tle prawa unijnego. Zeszyty Prawnicze, 17(1), 93-105.

Kanownik, G. (2017). Bezpieczeństwo pacjenta a dostępność do usług zdrowotnych. Finanse, Rynki Finansowe, Ubezpieczenia, (85), 621-632. https://doi.org/10.18276/ frfu.2017.1.85-49

Król, R., Brodny, J. (2018). Rola i znaczenie telemedycyny w leczeniu chorób serca. Zeszyty Naukowe. Organizacja i Zarządzanie, 117, 287-303. https://doi.org/10.29119/16413466.2018.117.19

Krysta, K., Romańczyk, M., Diefenbacher, A., Krzystanek, M. (2021). Telemedicine Treatment and Care for Patients with Intellectual Disability. International Journal of Environmental Research and Public Health, 18(4), 1746, 1-12. https://doi.org/10.3390/ ijerph18041746

Krzepota, J., Sadowska, D. (2015). Aktywność fizyczna a ryzyko upadku u osób z dysfunkcją narządu wzroku. Marketing i Rynek, 11 (CD), 187-192.

Krzystanek, M., Matuszczyk, M., Krupka-Matuszczyk, I., Koźmin-Burzyńska, A., Segiet, S., Przybyło, J. (2020). Telewizyta (e-wizyta) na czas kryzysu epidemicznego-rekomendacje w zakresie prowadzenia wizyt online w opiece psychiatrycznej. Psychiatria, 17(2), 61-65. https://doi.org/10.5603/PSYCH.2020.0011

Kufel, J., Kret, J., Kozik, P., Szydziak, M. (2019). Telemedycyna - przegląd zastosowania w wybranych krajach. W: A. Danielewska, B. Wrzyszcz (red.), Biomedycyna i zagadnienia pokrewne, t. 1. (s. 172-181). Wydawnictwo Naukowe TYGIEL. http://bc.wydawnictwo-tygiel. pl/public/assets/342/Biomedycyna\%20i\%20zagadnienia\%20pokrewne.\%20Tom\%201.pdf

Kuper, H., Mactaggart, I., Dionicio, C., Cañas, R., Naber, J., Polack, S. (2018). Can we achieve universal health coverage without a focus on disability? Results from a national case-control study in Guatemala. PloS one, 13(12), e0209774, 1-12. https://doi.org/10.1371/ journal.pone.0209774

Li, J.O., Liu, H., Ting, D., Jeon, S., Chan, R., Kim, J.E., Sim, D.A., Thomas, P., Lin, H., Chen, Y., Sakomoto, T., Loewenstein, A., Lam, D., Pasquale, L.R., Wong, T.Y., Lam, L.A., Ting, D. (2021). Digital technology, tele-medicine and artificial intelligence in ophthalmology: A global perspective. Progress in retinal and eye research, 82, 100900. https://doi.org/10.1016/j.preteyeres.2020.100900

Lim, H.J., Im, A., Cho, H.A. (2019). The association between visual impairment and dental care utilization in the Korean elderly. Archives of gerontology and geriatrics, 81, 18-24. https://doi.org/10.1016/j.archger.2018.11.005 
Lin, M.H., Yuan, W.L., Huang, T.C., Zhang, H.F., Mai, J.T., Wang, J.F. (2017). Clinical effectiveness of telemedicine for chronic heart failure: a systematic review and meta-analysis. Journal of investigative medicine: the official publication of the American Federation for Clinical Research, 65(5), 899-911. https://doi.org/10.1136/jim-2016-000199

Łęcka, I. (2011). Telemedycyna w krajach tropikalnych i subtropikalnych Afryki i Azji. Perspektywa geograficzna. Uniwersytet Warszawski.

Mack, H.G., Fraser-Bell, S. (2021). „COVID new normal” in ophthalmology: Implications for ophthalmologists, eye care, ophthalmic education and research. Clinincal \& Experimental Ophthalmology, 49, 9-11. https://doi.org/10.1111/ceo.13898

Mann, D.M., Chen, J., Chunara, R., Testa, P.A., Nov, O. (2020). COVID-19 transforms health care through telemedicine: Evidence from the field. Journal of the American Medical Informatics Association: JAMIA, 27(7), 1132-1135. https://doi.org/10.1093/jamia/ocaa072

Mashima, P., Doarn, Ch. (2008). Overview of Telehealth activities in speech-language oathology. Telemedicine and e-Health, 14(10), 1101-1107. https://doi.org/10.1089/ tmj.2008.0080

Masłyk, T., Migaczewska, E. (2014). Portret aktywnego, niepełnosprawnego użytkownika sieci internetowej. Niepetnosprawność: zagadnienia, problemy, rozwiązania, 3(12), 25-39.

Meyer, S.B., Luong, T.C., Mamerow, L., Ward, P.R. (2013). Inequities in access to healthcare: analysis of national survey data across six Asia-Pacific countries. BMC Health Serv Res 13, 238. https://doi.org/10.1186/1472-6963-13-238

Mold, F., Hendy, J., Lai, Y.L., de Lusignan, S. (2019). Electronic Consultation in Primary Care Between Providers and Patients: Systematic Review. JMIR medical informatics, 7(4), e13042. https://doi.org/10.2196/13042

Morrison, E.H., George, V., Mosqueda, L. (2008). Primary care for adults with physical disabilities: perceptions from consumer and provider focus groups. Family medicine, 40(9), 645-651. https://fammedarchives.blob.core.windows.net/imagesandpdfs/fmhub/fm2008/ October/Elizabeth645.pdf

Najwyższa Izba Kontroli (2015). Realizacja przez podmioty wykonujące zadania publiczne obowiazku dostosowania ich stron internetowych do potrzeb osób niepełnosprawnych. Informacja o wynikach kontroli. https://www.nik.gov.pl/kontrole/D/15/505/

Narodowy Fundusz Zdrowia (2020). Raport z badania satysfakcji pacjentów korzystających $z$ teleporad u lekarza Podstawowej Opieki Zdrowotnej w okresie epidemii COVID-19. https://www.nfz.gov.pl/download/gfx/nfz/pl/defaultaktualnosci/370/7788/1/raport_-_teleporady_u_lekarza_poz.pdf

Omyła-Rudzka, M. (2020). Opieka medyczna w czasie pandemii. Komunikat z badań. Centrum Badania Opinii Społecznej, 88/2020, 1-9, https://www.cbos.pl/SPISKOM.POL/2020/K_088_20.pdf

Pankowska, A., Rostkowska, J., Skarżyński, H. (2015). Telerehabilitacja dorosłych pacjentów korzystających z aparatów słuchowych i/lub implantów ślimakowych. Nowa Audiofonologia, 4(2), 81-85. https://www.nowaaudiofonologia.pl/Telerehabilitacja-doroslychpacjentow-korzystajacych-nz-aparatow-sluchowych-i-lub,129628,0,1.html 
Program Dostępność Plus. https://www.funduszeeuropejskie.gov.pl/strony/o-funduszach/ fundusze-europejskie-bez-barier/dostepnosc-plus/o-programie/

Reed-Jones, R.J., Solis, G.R., Lawson, K.A., Loya, A.M., Cude-Islas, D., Berger, C.S. (2013). Vision and falls: a multidisciplinary review of the contributions of visual impairment to falls among older adults. Maturitas, 75(1), 22-28. https://doi.org/10.1016/j.maturitas.2013.01.019

Robakowski, P., Synoweć, J. (2020). Polityka zdrowotna RP-co zmieniło się w dobie COVID-19. Studia Polityczne, 48(3), 85-106. https://doi.org/10.35757/STP.2020.48.3.04

Ruzik-Sierdzińska, A., Sierdziński, J. (2018). Koszty i korzyści rozwiązań telemedycznych. Studia i Prace Kolegium Zarządzania i Finansów, 165, 49-61. https://econjournals. sgh.waw.pl/SiP/article/view/816/718

Salminen, A-L., Karhula, M.E. (2014). Young persons with visual impairment: Challenges of participation. Scandinavian Journal of Occupational Therapy, 21(4), 267-276. https://doi. org/10.3109/11038128.2014.899622

Scholz, F., Yalcin, B., Priestley, M. (2017). Internet access for disabled people: Understanding socio-relational factors in Europe. Cyberpsychology: Journal of Psychosocial Research on Cyberpspace, 11(1), 1-13. https://doi.org/10.5817/CP2017-1-4

Siegel, C.A. (2017). Transforming gastroenterology care with telemedicine. Gastroenterology, 152(5), 958-963. https://doi.org/10.1053/j.gastro.2017.01.048

Szeroczyńska, M. (2015). Dyskryminacja osób z niepełnosprawnościa w ochronie zdrowia. Polskie Towarzystwo Prawa Administracyjnego. http://ptpa.org.pl/site/assets/files/ochrona\%20zdrowia.pdf

Tang, R.A., Morales, M., Ricur, G., Schiffman, J.S. (2005). Telemedicine for eye care. Journal of Telemedicine and Telecare, 11(8), 391-396. https://doi. org/10.1177/1357633X0501100803

Tarricone, R., Rognoni, C. (2020). What can health systems learn from COVID-19? European Heart Journal Supplements: Journal of the European Society of Cardiology, 22(Suppl Pt), P4-P7. https://doi.org/10.1093/eurheartj/suaa185

Ting, D., Ang, M., Mehta, J.S., Ting, D. (2019). Artificial intelligence-assisted telemedicine platform for cataract screening and management: a potential model of care for global eye health. The British journal of ophthalmology, 103(11), 1537-1538. https://doi.org/10.1136/ bjophthalmol-2019-315025

Ting, D.S.J., Deshmukh, R., Said, D.G., Dua, H.S. (2020). The impact of COVID-19 pandemic on ophthalmology services: are we ready for the aftermath? Therapeutic Advances in Ophthalmology. https://doi.org/10.1177/2515841420964099

Ting, D., Foo, V.H., Yang, L., Sia, J.T., Ang, M., Lin, H., Chodosh, J., Mehta, J.S., Ting, D. (2021). Artificial intelligence for anterior segment diseases: Emerging applications in ophthalmology. The British journal of ophthalmology, 105(2), 158-168. https://doi. org/10.1136/bjophthalmol-2019-315651

Twardowski, A. (2018). Społeczny model niepełnosprawności-analiza krytyczna. Studia Edukacyjne, 48, 97-114. https://repozytorium.amu.edu.pl/bitstream/10593/23791/1/ SE\%2048_2018_Andrzej_Twardowski.pdf 
Valdez, R.S., Rogers, C., Claypool, H., Trieshmann, L., Frye, O., Wellbeloved-Stone, C., Kushalnagar, P. (2021). Ensuring full participation of people with disabilities in an era of telehealth. Journal of the American Medical Informatics Association, 28(2), 389-392. https://doi.org/10.1093/jamia/ocaa297

Vujosevic, S., Modena, E. (2016). Diabetic retinopathy in Italy: epidemiology data and telemedicine screening programs. Journal of diabetes research, 1-6. https://doi.org/ $10.1155 / 2016 / 3627465$

Waterman, H., Webb, C. (1992). Visually impaired patients' perceptions of their needs in hospital. Nursing practice, 5(3), 6-9. PMID: 1625764.

Wettstein, M., Spuling, S.M., Hans-Werner-Wahl, H.V. (2021). Associations of Self-Reported Vision Problems with Health and Psychosocial Functioning: A 9 Year Longitudinal Perspective. British Journal of Visual Impairment, 39(1), 31-52. https://doi.org/ $10.1177 / 0264619620961803$

Wołoszyn-Cichocka, A. (2017). Konstytucyjny obowiązek zapewnienia szczególnej opieki zdrowotnej dzieciom, kobietom ciężarnym, osobom niepełnosprawnym i osobom w podeszłym wieku przez władze publiczne. Annales Universitatis Mariae Curie-Skłodowska, sectio G-Ius, 64.1, 225-241. https://doi.org/10.17951/g.2017.64.1.225

Wong, T.Y., Sabanayagam, Ch. (2019). The war on diabetic retinopathy: where are we now? Asia-pacific Journal of Ophthalmology (Philadelphia, Pa.), 8(6), 448-456. https://doi. org/10.1097/APO.0000000000000267

World Health Organization (2019). World report on vision. https://www.who.int/publications/i/item/world-report-on-vision

Wrześniewska-Wal, I., Hajdukiewicz, D. (2020). Telemedycyna w Polsce-aspekty prawne, medyczne i etyczne. Studia Prawnoustrojowe, 50, 509-524. https://doi.org/10.31648/ sp.6061

Żuchowska-Skiba, D. (2020). Wykluczenie cyfrowe osób z niepełnosprawnościami - perspektywy badawcze. W: G. Całek, J. Niedbalski, D. Żuchowska-Skiba (red.). Jak badać zjawisko niepetnosprawności. Szanse i zagrożenia założeń teoretycznych i metodologicznych studiów nad niepelnosprawnością (s. 195-210). Wydawnictwo Uniwersytetu Łódzkiego.

\section{AKTY PRAWNE}

Rozporządzenie Ministra Zdrowia z 31 października 2019 r. zmieniające rozporządzenie w sprawie świadczeń gwarantowanych z zakresu podstawowej opieki zdrowotnej. Dz.U. 2019 poz. 2120.

Ustawa z dnia 15 kwietnia 2011 r. o działalności leczniczej. Dz.U. 2011 nr 112 poz. 654.

Ustawa z dnia 28 kwietnia 2011 r. o systemie informacji w ochronie zdrowia. Dz.U. 2011 nr 113 poz. 657. 